\title{
Young people's career choices based on employer branding
}

\author{
ANDRea Poleto OltramarI ${ }^{1}$ \\ ROSANA CÓRDOVA ${ }^{2}$ \\ MARIA JOSÉ TONELLI ${ }^{3}$ \\ 1 UNIVERSIDADE FEDERAL DO RIO GRANDE DO SUL (UFRGS) / \\ Programa de Pós-Graduação em Administração, Porto Alegre - RS, Brazil \\ 2 Universidade federal do Rio GRANde do Sul (UFRGS) / Escola de AdMinistração, Porto Alegre - RS, Brazil \\ ${ }^{3}$ FundaçÃo Getulio Vargas (FGV EAESP) / Escola de AdministraçÃo de EMPreSAS de SÃo Paulo, \\ Departamento de Administração Geral e Recursos humanos, SÃo PaUlo - SP, BRAZIL
}

\begin{abstract}
This article critically discusses the relevance of brands in young undergraduate students' choices when looking for internships and jobs. The research is based on the debate around the modern concepts of employer branding, consumption and lifestyle, and prosumption and co-creation. Interviews were conducted with 18 students at the end of an undergraduate program in business administration at a public university in the south of Brazil. The main results show that younger students become prosumers of their employer's brands and their careers are based on seeking to work for the best brands, which is associated to intermittent jobs and vulnerable work relationships. However, the employers do not seem to offer enough elements to retain young workers.
\end{abstract}

Keywords: Labor. Consumption. Employer branding.

\section{Trabalhador-consumidor: a atração de jovens pelo employer branding na escolha profissional}

\section{Resumo}

O objetivo neste artigo discutir criticamente a importância da marca para a escolha profissional de jovens estudantes de graduação que prospectam vagas em empresas. A pesquisa A pesquisa se baseia no aparato conceitual contemporâneo de employer branding, consumo e estilo de vida, prosumption e cocriação. Os procedimentos de coleta de dados incluíram entrevistas semiestruturadas com dezoito estudantes ao final do curso de Administração de uma Universidade Federal no sul do país. Os principais resultados apontam que os jovens tornam-se prosumidores das marcas empregadoras; que a carreira amparada pela busca da melhor marca mostra-se como uma empreitada e está associada a trabalhos intermitentes, o que torna as relações de trabalho cada vez mais vulneráveis. Mas, apesar de o jovem trabalhador escolher a marca empregadora, esta parece não ter atrativos suficientes para retê-lo numa carreira a longo prazo.

Palavras-chave: Trabalho. Consumo. Employer branding.

\section{Trabajador-consumidor: la atracción de jóvenes por el employer branding en la elección profesional}

\section{Resumen}

El objetivo de este artículo es realizar una discusión crítica sobre la importancia de la marca para la elección profesional de jóvenes estudiantes de graduación, que prospectan vacantes en empresas. La investigación se apoya en el debate conceptual contemporáneo sobre el employer branding, el consumo y el estilo de vida, prosumo y cocreación. Los procedimientos de recolección de datos incluyeron entrevistas semiestructuradas y observaciones sistemáticas con 18 estudiantes al final del curso de Administración de una universidad federal del sur del país. Los principales resultados apuntan que: los jóvenes se vuelven prosumidores de las marcas empleadoras; la carrera, amparada por la búsqueda de la mejor marca, se muestra como una empresa y está asociada a trabajos intermitentes, lo que hace que las relaciones de trabajo sean cada vez más vulnerables. Pero, a pesar de que la elección del joven trabajador se apoye en la marca empleadora, esta parece no tener los atractivos suficientes para retenerlo para una carrera a largo plazo.

Palabras clave: Trabajo. Consumo. Employer branding. 


\section{INTRODUCTION}

Studies linking work and consumption have been conducted by a number of authors who deal with: prosumption or co-creation. (CÓRDOVA, 2016; FONTENELLE, 2014, 2015a, 2015b; PRAHALAD and RAMASWAMY, 2004a, 2004b; TOFFLER, 1980); the consumer as value producer (CHERKOVSKAYA and LOAKER, 2016; DALE, 2012; FONTENELLE, 2015a), especially by way of the Internet (RITZER, 2014); ethical economy (ARVIDSSON, 2010; ARVIDSSON and PEITERSEN, 2013); immaterial labor (GORZ, 2003; LAZZARATO and NEGRI, 2001) and voluntary work (PEARCE, 1993), or free labor (ANDREJEVIC, 2013; HESMONDHALGH, 2013; TERRANOVA, 2003). While there are authors who point to the countless positive aspects of these new work formats, by which the consumer is brought into the very center of value creation based on co-creation processes (BOTSMAN and ROGERS, 2011; PRAHALAD and RAMASWAMY, 2004b), there are also critical perspectives that indicate the intense exploitation of workers based on prosumption (COMOR, 2010a, 2010b; FONTENELLE, 2014; GORZ, 2003; LAZZARATO and NEGRI, 2001, 2015a). This perspective, which deals with the relationship between work and consumption, also includes discussions about employer branding (EB). In this article we use an approximate translation for "employer branding" as being the concept of a company that manages its brand in order to support its image of being a good company to work for (AMBLER and BARROW, 1996; BACKHAUS and TIKOO, 2004; CHERTKOVSKAYA, WATT, TRAMER et al., 2013; DALE, 2012; DELL and AINSPAN, 2001; LAND and TAYLOR, 2010). This approach also aims to attract candidates, particularly by awakening in them a desire both to forge a career for themselves in the company and to ensure that their résumés include spells working in companies that promote a good image in the market. There is no need, therefore, to be a company employee for an employer brand relationship to exist. The candidate often develops a socially cooperative relationship with employer brand companies, especially because they divulge good references about their brands via their wide network of contacts. In addition to working in the company, the employee identifies with its brand and consumes it. A brand can be a name, a sign, a symbol or a combination of all three, which serves to identify what an organization has to offer and differentiates it from its competitors (CHURCHILL and PETER, 2003; LOURO, 2000).

Although they are few in number, Brazilian studies on this subject deal with this relationship between employees and brands in a positive way (OLTRAMARI, TONELLI and COSTA, 2015; REIS and BRAGA, 2016). Our objective in this article is to discuss critically how important incorporating brand is for undergraduate students who are looking for job vacancies and opportunities for building their careers. We try to understand how, in their search for work, these young people have incorporated the meaning of prosumer. We first present the basic concepts of this work, which are employer branding, co-creation and prosumption. We then present the methodological procedures that were used in collecting, analyzing and discussing the data. This is followed by the final considerations.

\section{CONCEPTS}

\section{Employer branding}

Ambler and Barrow (1996) defined employer branding on the basis of on an exploratory study they conducted in companies in the UK into the importance of applying brand management techniques in human resource management. The study concluded that the concept of employer branding is potentially valuable for organizations, and that making use of brand management techniques in human resource management adds value to corporate worth from a consumer perspective. For the authors, the definition of employer brand is: "[...] the package of functional, economic and psychological benefits that are provided by employment and identified with the employing company" (AMBLER and BARROW, 1996, p. 187). It is important to add that employer branding is also related to building an image in the minds of potential workers that this particular space is a great place to work (BERTHON, EWING and HAH, 2005).

Aggerholm, Andersen and Thomsen's (2011) survey of the topic shows literature that includes: 1) a static notion of employer branding, in which employer brand propositions are defined by brand strategists based on the identity of the brand;2) the exposure and transmission of employer branding propositions internally (internal branding helps the organization align corporate culture with brand interests) and externally (based on an understanding that advertising should reach all stakeholders and not just the end consumer); 3 ) linear employer branding practices that focus only on the attractiveness of the employer and 
the productivity of the employee; and 4) a channel for enhancing consumer experiences based on an integrated look at brand management that enables consumer loyalty and performance to be influenced.

For Aggerholm, Andersen and Thomsen (2011), employer branding studies adopt an outdated notion of brand management that is rooted in functionalist ideas of employer-employee relationships and that fail because they do not present the organizational challenges and pressures of society. A gap opens up, therefore, which allows us to think about the relationship with value co-creation, for example, as we notice a shift away from the locus of economic value production to the value co-creation locus (PRAHALAD and RAMASWAMY, 2004a, 2004b).

In recent studies in $E B$ and human resources, articles have discussed sustainable human resource management (APP, MERK and BUTTGEN, 2012), attractiveness dimensions (BERTHON, EWING and HAH, 2005; CHHABRA and SHARMA, 2014; WILDEN, GUDERGAN and LINGS, 2010) and human resources and social media (SIVERTZEN, NILSEN and OLAFSEN, 2013).

Research into employer branding carried out in Brazil in the administration area deals with young people from Generation $Y$ being attracted to and/or turned off by employer brands; these studies are either linked to the organizational culture of the company (OLIVEIRA and HONÓRIO, 2014), the selection, recruitment and retention of people (OLTRAMARI, TONELLI and COSTA, 2015) or policies for retaining young people (REIS and BRAGA, 2016). There are few studies on the subject, therefore, and because it is a very recent theme, a lot of research needs to be done into the concept of employer branding, co-creation and prosumption. In addition, a lot of the work that deals with the subject is conceptual; empirical data are rarely presented. This research, on the other hand, has taken data from interviews about how these concepts have been incorporated by young people in their search for work. To discuss co-creation and prosumption in more depth, however, we need to reflect on the search for lifestyles that are increasingly associated with consumption.

The main lifestyle driver of the consumer society is the ceaseless pursuit of happiness (BAUMAN, 2007, 2008). Baudrillard (2005) analyzes life that is associated with consumption and relates it also to "cathedrals of consumption", to shopping malls, to "pyramids of collapsing objects" (BAUDRILLARD, 2005, p. 16). This lifestyle completely invades existence and impregnates social relations. Cathedrals of consumption are associated with: images and information that are likely to have an accelerated obsolescence (BAUDRILLARD, 2005); waste (LIPOVETSKY, 1989) and; liberating and encouraging a rapid increase in individual spending. Consumers act in obeyance to a code, especially the code of thinking that is shared by the group and that adheres to excessive consumption, or abundance (BAUDRILLARD, 2005). Those who do not consume voraciously end up not belonging to the group. Social recognition also has to do with the current consumer society and the fact it is not happening may, in our liquid-modern society, result in continuous tension.

Consumption gains another dimension that has not yet been sufficiently explored (FONTENELLE, 2014) in labor or employment relationships. An example of this is that work and consumption become intertwined and it is impossible to separate work time from non-work time (LAZZARATO and NEGRI, 2001). Work also becomes consumption in immaterial capitalism (FONTENELLE, 2014), being therefore the "plenitude of abstract work" (OLIVEIRA, 2003). The Internet, for example, amplifies this phenomenon and clearly begins to include the possibility of consumers co-participating in the new product creation processes of companies (ARVIDSSON, 2005, 2006, 2008). Consumer and contemporary consumption, therefore, cannot be understood separately from the world of work and production (CÓRDOVA, 2016; FONTENELLE, 2015b).

Consumption is accelerating, which guarantees that goods are sold even before they are produced (ABíLIO, 2011). It is also a guarantee that workers (when they assume responsibility for servicing and selling the product to themselves) see themselves as capital (because in addition to consuming the product, they create it) and no longer as just the workforce.

Companies have used an employer brand strategy to attract and retain the best candidates and ensure that future employees engage with the company's culture and strategy (REIS and BRAGA, 2016). The employer brand company invests in its image, by showing everyone that it is an outstanding and excellent place to work. This strategy may be adopted because they believe that these same candidates and workers have great potential to publicize the company's brand as consumers and turn it into the consumption wish of many people. There are prosumer characteristics in candidates who gravitate towards job vacancies in employer brand companies, such as: these candidates doing unpaid work (TERRANOVA, 2003); consumption as an investment directed at work (FONTENELLE, 2015a, 2015b); and the social relationship investment and emotional involvement with the brand and with the product as a precursor of the trust that is to be established (ARVIDSSON, 2005). Above all, prosumers work even though they receive no financial compensation (RITZER, DEAN and JURGENSON, 2012). The current consumer society is pursuing something that is transitory and looking for trust, a concept that will be discussed in the next section. 


\section{Co-creation and prosumption: at the roots of consumption}

A series of articles that appeared, especially after 2000, points out that we can no longer look at production alone, without considering the consumer (see GABRIEL and LANG, 2008; RITZER, GOODMAN and WIEDENHOFT, 2001). It is in the Third Wave (TOFFLER, 1980), however, that we see for the first time that the boundaries between production and consumption are blurred; in other words, it is impossible to think about one without the other.

Already in the 1980s, for example, the word prosumption referred to the process by which the boundaries that separated producer from consumer became jumbled (GABRIEL and LANG, 2008). Nowadays this term has gained in strength and is increasingly associated with producing value for capitalism (ARVIDSSON, 2008; FONTENELLE, 2015b). This term is essentially "[...] hailed as a way of empowering the consumer. Based on a critical strand, authors point to a new way of selling and exploiting labor" (FONTENELLE, 2015b, p. 84).

Selling and exploiting labor may result in work extending to the sphere of consumption (OLIVEIRA, 2003). For example, many consumer co-creation, co-production and co-participation processes are included in the sphere of work. This is the concept of "do-it-yourself", as proposed by Toffler (1980).

It is the prosumer who interacts with tools like YouTube, Wikipedia, Facebook, Booking.com, Amazon, etc. In some cases these prosumers are the protagonists in content creation and management, while in others they review hotels, books and services in general. In addition to creating the product and service, there are also self-checkouts and self-check-ins as both an individual and a collective brand-sharing experience (RITZER, 2014).

In this logic, the individual also becomes the "self-manager" (LÓPEZ-RUIZ, 2007), a term derived from studies into immaterial labor (LAZZARATO and NEGRI, 2001). For the authors, immaterial labor is a new production-consumption relationship, in which work demands have an impact on the intellectual and affective capacity of workers, resulting in a greater take-over of their personal and professional lives.

The superimposing of production time on leisure time can also be observed from the viewpoint of the sharing economy and the processes of co-creation. Some of the literature (see AIGRAIN and AIGRAIN, 2012; BOTSMAN and ROGERS, 2011; PRAHALAD and RAMASWAMY, 2004b; TAPSCOTT and WILLIAMS, 2010) uses terms like 'sharing economy', 'collaborative consumption' and 'co-creation' without necessarily doing so from a critical perspective, according to which, for example, aspects related to new forms of exploitation and the precarious nature of work are analyzed (GILL and PRATT, 2008).

Some authors, however, address the issue of co-creation in a critical manner: Zwick, Bonsu and Darmody (2008, p. 168) show how people in the marketing area "[...] typically consider having relationships with consumers as something that companies should aspire to, because good relations translate into higher profits." By deconstructing the invention of "consumer relations" in marketing thinking, Zwick, Bonsu and Darmody (2008) distance themselves from Prahalad and Ramaswamy's (2004b) concept of co-creation to find dialogues that conceptualize the co-creation of the general logic of production in capitalist information economies (HESMONDHALGH, 2010; TERRANOVA, 2003) and in critical theorizations about brand value (ARVIDSSON, 2006).

According to Zwick, Bonsu and Darmody (2008, p. 182), the "[...] notion of co-creation represents a sophisticated technology for governing consumers, where the added value generated is based on the frequent appropriation of the creative and socially cooperative work of consumers." Despite having this concept as its basis and knowing its importance, this is still a frontier that has not been completely crossed, even though greater control over markets is being repeatedly sought (ZWICK, BONSU and DARMODY, 2008). The concept of prosumer, the producer-consumer, or as we are using in this article, the concept of worker-consumer, is subsumed in new forms of work organization and new forms of recruitment and selection. We have just indicated that the separation between individual-work-company-consumption is no longer as clear as it used to be. The concepts of worker and consumer are intermingled and companies use brand consumption to increase the loyalty of workers, who are attracted by the values and social meanings of these enterprises $c$.

But while the concept of worker-consumer is debated in both corporate practice and academic studies, few empirical studies seek to show how brand is incorporated by workers, especially those who are starting out in their careers. As a contribution to this debate, the empirical research presented in the next section provides some insight into the relationship of employer brand companies with the professional choices of young people who are concluding a course in business administration. 


\section{METHODOLOGICAL PROCEDURES}

This study adopts a qualitative approach to the question and uses semi-structured interviews and systematic observations, which result in a deeper interpretation of the relationships that are established between the categories being analyzed (FLICK, 2004; SYMON and CASSEL, 2012; TRIVIÑOS, 1987). The choice of method also translates into an epistemological view that has practical consequences for the choice of study, while the theoretical approach we adopted shapes the way the data were collected and analyzed (SYMON and CASSEL, 2012). To respond to the objective of the research, in other words, to understand how employer branding is constructed for students at the end of a business administration course in a federal university in the south of Brazil, we interviewed 18 young people between 21 and 25 years old, 5 women and 13 men. Those interviewed were selected because of their accessibility and by indication, and by the availability of the interviewees themselves.

The interview script contained the following questions associated with employer brand: knowledge of the brands; the reason for applying; the advantages and disadvantages of working in an employer brand company; the reason for building a career; what they expect to find in an employer brand company; what do employer brand companies have that other companies do not, and vice versa; and give the name of an employer brand (the first that comes to mind). In Box 1 we present a summary of the interviewees' data. It should be noted that all the young people we interviewed were students at the end of their undergraduate course, but they were all also working at the same time in different types of company, either as interns or employees.

As happens with qualitative research, we came across a world of different meanings, both when we were collecting the data and when they were subsequently being analyzed. The categories were structured a posteriori using content analysis (MINAYO, 2001). The content of what was said, recorded and transcribed was discussed by the authors in such a way as to seek out the meanings behind the data. The content was also systematized according to the precepts of exhaustivity, homogeneity and pertinence (BARDIN, 2016).

\section{Box 1}

Characteristics of the interviewees

\begin{tabular}{|c|c|c|c|}
\hline Interviewee & Sex & Age & Function at the time of the interview \\
\hline E1 & $M$ & 22 & Intern \\
\hline E2 & M & 21 & Intern in a state-owned company \\
\hline E3 & M & 23 & Bank worker \\
\hline E4 & $\mathrm{F}$ & 23 & Analyst in a retailer \\
\hline E5 & M & 23 & Entrepreneur \\
\hline E6 & M & 21 & Assistant in a family-owned company \\
\hline E7 & M & 22 & Volunteer work with AIESEC \\
\hline E8 & M & 21 & Intern in a small company \\
\hline E9 & M & 21 & Employee of a startup \\
\hline E10 & M & 23 & At the time of the interview had no internship and/or professional activity \\
\hline E11 & $\mathrm{F}$ & 23 & Intern in a state-owned company \\
\hline E12 & M & 21 & Junior volunteer in a company \\
\hline E13 & $\mathrm{F}$ & 23 & Intern in a small company \\
\hline E14 & M & 24 & Intern in a multinational company in Panama \\
\hline E15 & $\mathrm{F}$ & 24 & Bank worker \\
\hline E16 & $\mathrm{F}$ & 23 & Employee in a company in the telecommunications sector \\
\hline E17 & $\mathrm{F}$ & 25 & Intern taking part in selection processes \\
\hline E18 & $\mathrm{F}$ & 22 & Employee in a company in the cosmetics industry \\
\hline
\end{tabular}

Source: Elaborated by the authors. 
According to the principles of exhaustivity, homogeneity and pertinence (BARDIN, 2016), what was said was classified and later analyzed. For Moraes (2007), content analysis is a process of text deconstruction, from which units of analysis emerge that are identified on the basis of a meaning that is relevant to the purpose of the research. We established the following as the nuclei of the meanings of what was said: 1) employer brand; and 2) the prosumer intern: the producer/consumer of the employer brand company.

\section{Description, analysis and discussion of the results}

We started by highlighting the main points of what the interviewees said about the importance of the brand, and then looked at the discussion about employer brand and the prosumer intern.

The students point out that employer brand is of practical use since it "adds to the résumé" (E1), but it also reveals "healthier companies" (E3) since they have been in the market longer. These students also emphasize, however, that the values and purposes of companies need to be aligned with their own values (E5). Box 2 summarizes how important the brand to is to each of the interviewees and to their trajectories.

\section{Box 2}

\section{The importance of employer brand}

\begin{tabular}{|c|c|c|c|c|c|}
\hline Students/Sex & Semester & Sex & Importance of the brand & Age & Career path of the students \\
\hline E1 & 9 & M & $\begin{array}{l}\text { "Working with an employer brand [company] adds a } \\
\text { lot to the résumé, but that's not all that matters. Well- } \\
\text { being is important to me." }\end{array}$ & 22 & $\begin{array}{l}\text { He has worked as an intern in various } \\
\text { places for a short time. He is currently } \\
\text { focusing on graduating and preparing } \\
\text { for the selection process at an } \\
\text { employer brand company. }\end{array}$ \\
\hline E2 & 9 & M & $\begin{array}{l}\text { He believes the employer brand makes for better } \\
\text { employability, since he will be recognized from the } \\
\text { résumé as having worked in a company with brands. }\end{array}$ & 21 & Internship in a public body. \\
\hline E3 & 10 & M & $\begin{array}{l}\text { He believes that employer brand companies are } \\
\text { "healthier" in the sense that they can survive crises } \\
\text { more easily because they are already stabilized in } \\
\text { the market. He also believes that while well-being is } \\
\text { important, a reputation for working in a place with a } \\
\text { strong brand opens doors. But he values the stability } \\
\text { relationship a lot. }\end{array}$ & 23 & $\begin{array}{l}\text { He first worked as an intern in a bank, } \\
\text { after which he worked at one of the } \\
\text { largest companies in Rio Grande } \\
\text { do Sul. }\end{array}$ \\
\hline E4 & 10 & $\mathrm{~F}$ & $\begin{array}{l}\text { Working for an employer brand company adds a lot to } \\
\text { the résumé, but what is important for her is having that } \\
\text { particular experience. She believes that the values of } \\
\text { the brand need to be aligned with ones own. }\end{array}$ & 23 & $\begin{array}{l}\text { She was an intern in an employer } \\
\text { brand retailer. She is currently } \\
\text { preparing to graduate. }\end{array}$ \\
\hline E5 & 8 & M & $\begin{array}{l}\text { He believes that an employer brand company is } \\
\text { undoubtedly an attractive feature in the résumé. But } \\
\text { you have to have a purpose and feel good when working. }\end{array}$ & 23 & $\begin{array}{l}\text { He has been an intern in a midsize } \\
\text { company and is currently looking to } \\
\text { set up his own company. }\end{array}$ \\
\hline E6 & 8 & $M$ & $\begin{array}{l}\text { He believes that a company with a name is undoubtedly } \\
\text { very well-recognized. He says he was "indoctrinated" } \\
\text { by his family to seek multinational companies because } \\
\text { he will get a great professional and financial return. He } \\
\text { believes that people take into account the reputation } \\
\text { of working for a brand. But he also believes that there } \\
\text { has to be quality of life at work. }\end{array}$ & 22 & $\begin{array}{l}\text { He was an intern in several small, } \\
\text { family-owned companies. }\end{array}$ \\
\hline
\end{tabular}


Continue

\begin{tabular}{|c|c|c|c|c|c|}
\hline Students/Sex & Semester & Sex & Importance of the brand & Age & Career path of the students \\
\hline E7 & 8 & M & $\begin{array}{l}\text { He chose to work at AIESEC as he would grow more in } \\
\text { terms of management than in any other company. But } \\
\text { of course, when you go to work for a company, before } \\
\text { starting you'll check out very well if its values are in } \\
\text { line with your own personal values. }\end{array}$ & 22 & $\begin{array}{l}\text { He was an intern in the finance area } \\
\text { in a law firm. He later decided to } \\
\text { dedicate himself to AIESEC, where } \\
\text { he works voluntarily. }\end{array}$ \\
\hline E8 & 9 & M & $\begin{array}{l}\text { He believes that if he had not worked for an employer } \\
\text { brand he would not be as well-established as he is } \\
\text { now. "Those who work in these companies have stood } \\
\text { out in the selection process and this is well regarded." } \\
\text { But it is important to him that the company is transparent } \\
\text { and working for a purpose. }\end{array}$ & 21 & $\begin{array}{l}\text { He first worked as an intern in a bank, } \\
\text { then in an employer brand company. } \\
\text { He decided to leave because he was } \\
\text { not being recognized by it. He opted } \\
\text { for a smaller company where he could } \\
\text { develop more professionally. During } \\
\text { this time he participated in AIESEC } \\
\text { and the Academic Center. }\end{array}$ \\
\hline E9 & 8 & M & $\begin{array}{l}\text { Working in an employer brand company is a résumé } \\
\text { strategy. But no brand will align with all his values. }\end{array}$ & 21 & $\begin{array}{l}\text { He was first an intern in a not so well- } \\
\text { known bank. Later he went to another } \\
\text { with a good reputation, while he was } \\
\text { working as a volunteer in the Academic } \\
\text { Center. He was then invited to work } \\
\text { at a startup. He accepted because it } \\
\text { was aligned with his purpose in life. }\end{array}$ \\
\hline E10 & 9 & M & $\begin{array}{l}\text { He believes that working in an employer brand } \\
\text { company is a great experience, because it shows you } \\
\text { a multinational vision. But you have to enjoy being } \\
\text { there too. }\end{array}$ & 23 & $\begin{array}{l}\text { At the moment he is getting more } \\
\text { involved with the academic area. } \\
\text { Later he's going to try and set up his } \\
\text { own company. }\end{array}$ \\
\hline E11 & 8 & $\mathrm{~F}$ & $\begin{array}{l}\text { "We know that undeniably for many having a large } \\
\text { company in the résumé carries a lot of weight, but } \\
\text { there's also the issue of competence; you often end } \\
\text { up feeling "drained". A professor once called me and } \\
\text { said - 'you have to choose whether you want to be } \\
\text { in big fish in a small pond, or a small fish in a mighty } \\
\text { ocean'. In the small company, you do everything and } \\
\text { sometimes this can help you grow much more than in a } \\
\text { large company, but you also have the option of stability } \\
\text { and development. There are companies with a very } \\
\text { good training program in the internships. Sometimes } \\
\text { you have a very good development program in the } \\
\text { internship. You have to do a lot of research into an } \\
\text { employer brand company before trying to join it to see } \\
\text { if what they say matches the reality." }\end{array}$ & 23 & $\begin{array}{l}\text { She was an intern in a public body } \\
\text { and a local authority. }\end{array}$ \\
\hline E12 & 10 & M & $\begin{array}{l}\text { He believes that an employer brand company adds } \\
\text { weight to the résumé. However, it has to be a nice } \\
\text { environment. The work environment carries more } \\
\text { weight than the company's name or money/salary ... }\end{array}$ & 21 & $\begin{array}{l}\text { He is part of the junior company. He } \\
\text { believes he would have a lot more } \\
\text { challenges there. }\end{array}$ \\
\hline E13 & 9 & $\mathrm{~F}$ & $\begin{array}{l}\text { She believes that an internship in a large multinational } \\
\text { company broadens your point of view. She says that it } \\
\text { certainly makes a big difference in the résumé as far } \\
\text { as society is concerned and if you want to apply for a } \\
\text { position in a sought-after company. }\end{array}$ & 23 & $\begin{array}{l}\text { Her first internship was in a small } \\
\text { company. Then she underwent a } \\
\text { selection process to join one of the } \\
\text { largest companies in Rio Grande do } \\
\text { Sul. But after a while, she went back } \\
\text { to the old internship for a question } \\
\text { of purpose and values. }\end{array}$ \\
\hline E14 & 10 & M & $\begin{array}{l}\text { He believes it is very important to have an employer } \\
\text { brand company in the résumé because it gives the } \\
\text { person a sense of the world that no small company } \\
\text { could give. }\end{array}$ & 24 & $\begin{array}{l}\text { His only internship was in an employer } \\
\text { brand company that then employed } \\
\text { him. He has now been transferred } \\
\text { by the same company to Panama. }\end{array}$ \\
\hline
\end{tabular}




\begin{tabular}{|c|c|c|l|c|c|}
\hline E15 & 10 & $F$ & $\begin{array}{l}\text { A résumé strategy, but also because the pay was } \\
\text { among the best for working just six hours a day. But } \\
\text { she believes you have to feel good where you work. }\end{array}$ & 24 & $\begin{array}{l}\text { Her first internship was in a large } \\
\text { bank, but she did not feel she was } \\
\text { recognized and is currently working } \\
\text { in another, smaller company, but she } \\
\text { is developing professionally. }\end{array}$ \\
\hline E16 & 10 & $F$ & $\begin{array}{l}\text { She would like to work for an employer brand company } \\
\text { because she believes that the pay is higher and the } \\
\text { working conditions are better. }\end{array}$ & 23 & $\begin{array}{l}\text { She is currently working as a } \\
\text { telecommunications analyst, but } \\
\text { studying to pass her civil service } \\
\text { exams. }\end{array}$ \\
\hline E17 & 10 & $F$ & $\begin{array}{l}\text { She believes that having worked in an employer brand } \\
\text { company adds a lot to the résumé. }\end{array}$ & 25 & $\begin{array}{l}\text { She is an intern in a company and } \\
\text { is participating in several selection } \\
\text { processes. }\end{array}$ \\
\hline E18 & 9 & $F$ & $\begin{array}{l}\text { She wants to work in employer brand companies in } \\
\text { various countries around the world. }\end{array}$ & 22 & $\begin{array}{l}\text { An employee in the cosmetics } \\
\text { industry. }\end{array}$ \\
\hline
\end{tabular}

Source: Elaborated by the authors.

From analyzing the interviews, two main themes emerged: employer brand and the prosumer intern, which we now present.

\section{Employer brand}

In the words of some of these young people (E1, E3, E4, E5, E6, E8, E10, E11, E16 and E17) there is a strong wish to join an employer brand company. This wish is indicated by some authors (OLTRAMARI, TONELLI and COSTA, 2015) as an outstanding organizational image, which is based on strategies that are especially reflected in the company's people management policies, particularly compensation, career and quality of life at work all being in harmony, and in accordance with what Legge (2005) calls its hard people management strategies.

This wish is observed in what young people say about joining an employer brand company that has an outstanding organizational image. What is interesting, however, is that they did not say they wanted to remain in these companies, but they particularly wanted to be able to put in their résumé that they had worked for an employer brand company (they said they wanted to work at companies like Google, Dell, Netflix, and McDonald's). They cannot visualize their professional future being for more than five years in the same company, as revealed by the words of E7, with which E1, E3, E5, E9, E10, E12 and E17 in particular, agree.

I can't see myself making a career in a company for five years. The work is repetitive and that's demotivating. The company's product is also always going to be the same. There'll come a point when I'll get tired of the place. I want to try working in other big companies. That would be my career plan (E7).

Also according to some of those interviewed:

I think that staying two years in an employer brand company ought to make a difference in the résumé. Six months is a short time. Then we go looking for another company if we notice that the employer brand is not offering what we'd like (E1).

According to the interviewees, the average length of stay in a company is around three years, which they consider to be a very long time. The ephemeral nature of relationships and the acceleration of time are protagonists in the new relationship that is being established between workers and the organization (BAUDRILLARD, 2005; BAUMAN, 2007, 2008). In a society in which relationships are ephemeral, as Bauman (2007) and Lavretsky (2007a) have already announced, readiness, in other words, suddenly changing tactics and style, abandoning commitments and loyalties, and seeking opportunities that are more in accordance with the interviewee's current availability than with their own preferences, becomes the rule of thumb.

One of the points emphasized by the interviewees is the issue of working for several different companies, which is in line with Baumam's (2007) considerations about the importance of speed to the detriment of durability. Apart from this, boredom can produce a feeling of complacency, a characteristic that is not looked on favorably by either these young people or by the employers. The need for status can also be addressed from the moment they become part of the company's staff. Without 
knowing how human resource policies and practices are structured, the interviewees believe that employer brand companies have bigger budgets for investing in people and consequently they can invest more in qualifications and an international career, quite apart from the fact that the recruitment and selection policies are more sophisticated and use primarily social networks, according to what was said. For example, one of the interviewees (E2) says: "[...] I believe that the employer brand makes us more employable; that we're recognized in our résumé for the time we spent in a company with a brand." Whereas before the human resources area "seduced" workers with its policies (KEENOY, 1999; TOWNLEY, 2002), now they start "seducing" them even before they join the organization, especially since the brand begins to take on an important value for them. The brand itself, therefore, becomes an organizer of human resource processes and practices, because of its leading and influential position in hiring workers.

During the interviews it also seemed that young people who apply for a vacancy in the company do not know for certain what work they will be doing. They do not even know what the company actually sells, which is corroborated by E3: "When I joined the company, it was because I wanted to have experience in a strong brand. But I thought it was just product $X$ and when I got there I realized that these companies are much more than what you see in everyday life. There are various other products that go unnoticed."

Young people want companies to have a human resource policy that needs to be strong, as one of them exemplifies: "[...] employer brands have more career [opportunities], health insurance, benefits, flexible working hours, and an open communication channel" (E4). Although they argue that they took little advantage of such policies, they mention that they are very attractive and this also has to do with maintaining a good employer brand: "this helps with brand reputation" and "the brand has a purpose and [puts across] the idea of excellence." The brand acts as a lever, a resource that allows the company to perpetuate and maintain its status as being an "elite" organization. Access starts when they enter the undergraduate course, which can be considered as a "seal" for accessing employer brands. This seal of access does not seem to be worth anything to universities in general terms, but confirms the studies by Rocha-de-Oliveira, Piccinini and Bittencourt (2012), according to which becoming employed is not the same for all young people in the labor market.

The interviewees said they are even willing to be paid less if necessary, in order to join an employer brand company. They talk about a feeling of well-being because they are working in companies that, according to them, "are stable" (E7), which here contrasts with ephemerality and is a contradiction between the stability they seek and the urgency and haste they have in building a career. The consumption of employment may represent what López-Ruiz (2007) says about consumption being an investment; in other words, these companies receive an evaluative order in society and because they are an employer brand they end up being the object of consumption and investment by candidates. According to Ritzer, Dean and Jurgenson (2012), producers/consumers also often work without any financial compensation, being motivated more by status and belonging to the brand than by their own salary.

If they are not promoted or do not progress rapidly, after one or two years many think about pursuing a new challenge, thus showing they have little patience with waiting and building a career. The traditional contract format, with its promises of long-term security, has given way to a new type of short-term contract that is renewed on the basis of current needs and worker performance. Young people are believed to be looking for new challenges, because they have no patience with the work format and because the precariousness of their relationships pushes them towards this. For Bauman (2008, p. 46), who calls this kind of moment the 'rushed culture', "[...] time in the liquid-modern consumer society is neither cyclical nor linear, as it used to be for members of other societies [...] it is marked by disruption and discontinuity, by intervals that separate successive points and break the bonds between them. " For Bauman (2008) a liquid-modern environment is inhospitable to long-term planning, investment and storage.

Students enjoy change and mobility; they do not see themselves pursuing their careers in just one place, especially because there is a constant need to "nourish" themselves with new challenges, as Bauman (2008) says of the need to replace objects that are "outdated" in the perspective of the liquid-modern society. A career in employer brand companies, in particular, acquires a status of the promise of many benefits in relation to the professional life of students. It is interesting to note a certain relief in the interviewees' words when it comes to mobility, which is linked to the belief that if they are moving they are not being complacent, as they call it. In their policies companies also encourage this behavior, which is related to the consumption of employment and career speed. Life policy and the nature of interpersonal relationships tend to be reshaped in the likeness of the means and objects of consumption, along the lines suggested by the consumerist syndrome (BAUMAN, 2007). Career, therefore, has become a means to mobility and consuming employment. We perceive, therefore, 
that these young people are always aiming for the future rather than the present, using their careers as a springboard for something they imagine to be higher, that has more status, but that is absolutely intangible, because it is uncertain, whereas before it was a means to receiving remuneration for fulfilling their personal shopping desires; in other words, desire touches on something concrete.

Their careers are being increasingly built as managers of themselves, as literature has been presenting them (OLTRAMARI, 2015; OLTRAMARI and GRISCI, 2014). Brands are preeminent in students' lives, which attests to the behavior of "brand hunters" in their search for work. The brand, above all, allows students to advance in their careers and makes them work for the future, not the present - the brand is, above all, future capital.

The interviewees were also asked about the advantages and disadvantages of building a career based on employer brands. The fact that the candidate has worked for an employer brand company increases their chance of competing for a vacancy in the labor market. According to one of the students interviewed, who works in the people management area of a company: "[...] when there's a candidate who has done at least five years in an employer brand company, I look at them favorably; I think the candidate has a good résumé because they've worked for employer brands" (E20). Here again is evidence of the contradictions that appear and that feed young people's career choices and career building. The next topic will discuss prosumer and employer brand and the relationship between them.

\section{The intern prosumer: the producer-consumer of the employer brand company}

There is involvement, a possible connection between employer branding, the desire to consume the brand and the prosumer perspective (FONTENELLE, 2014, 2015b; RITZER, DEAN and JURGENSON, 2012); in other words, the desire to consume the employer brand company involves the worker's production-consumption that goes beyond the contractual hours of his/her workday and his/her compensation. The key element of this concept - prosumer - is that the worker does not necessarily see this as a bad thing, but as something that adds to their résumé; something that updates them and keeps them in the job vacancy circuit of employer brand companies. This is what we see in the words of E11 when she says that because she is working in a bank, she should use this bank's own card.

Brand managers have somehow understood that consumers play an important - we would say fundamental - role in producing shared meanings of what brand is (RITZER, DEAN and JURGENSON, 2012). Young students are prosumers who produce the meanings that surround employer brands, such as Google, Coca-Cola, and Facebook. There is "[...] a social relationship, a shared meaning, an emotional involvement that was not there before" (ARVIDSSON, 2005, p. 237). Such information is perceived in the conversation with E10, when he states that he has complete freedom to "help the brand" and sees this as something positive. This emotional involvement of the prosumer can also be found in the words of E7, who deliberately uses his own social network to share promotions and "retweet" information from the company he works for. It is also seen in what E8 says, when he claims he tries on shoes from the store where he works and then posts this activity on Instagram. None of this is seen as work by those interviewed.

With regard to this aspect of work vs. non-work, Arvidsson (2006) argues that it is no longer possible to indicate a phenomenological difference between productive work and unproductive consumption; in other words, there is a productive dimension of consumption (LAZZARATO and NEGRI, 2001). When one interviewee (E7) states that he stopped drinking CocaCola because he is an intern at Ambev, and another (E16) who, as an intern at an elevator company started to ride the elevator wherever she went outside of working hours, this is evidence of this non-differentiation. It is as if consumers were being invited to complete the products either materially or symbolically (ARVIDSSON, 2006). It is in this programmed interactivity (of which employer brand companies are constantly aware) that the main nucleus of contemporary brand management resides (ARVIDSSON, 2005, 2006).

One of the key concepts for understanding what it is to be considered a (good) employer brand lies in the effort that the talent attraction and retention sectors make to retain employees, or to ensure that the intern evolves and has an effective career. This is why there is a concern with the candidate identifying with the employer brand. By way of this mutual identification and, taking into account that we are talking about prosumer interns, it becomes possible, as Arvidsson (2006, p. 35) would say, "[...] to set to work the attention and any other affections that consumers may have". 
On the one hand we have employer brand companies that have a discourse about "attracting talent", which provide experiences and train young people to produce and co-create; they do so by taking advantage of the affections of these young people. On the other, we have young people who are looking for a recognized brand in the market where they can work and start their careers.

It is important to mention that consumption also has to do with voluntary work (TERRANOVA, 2003). When the interviewees refer to activities associated with voluntary work, which, in turn, help them in their strategy to join employer brand companies, their leisure time is being consumed by work, which thus assumes the characteristic of immaterial work, a situation in which their whole lifetime is invaded by work. Voluntary work is presented not as altruism, but as an investment in career, and so investments in immaterial labor are getting bigger and bigger (TERRANOVA, 2003). In the logic of immaterial labor there is a desire to continue investing in non-work time, especially studying strategic ways to build a career, as reported by one interviewee (E6): "[...] I study American football outside of working hours because I know that this information will add value to both the company and my résumé." In the logic of free labor, information is offered and received without the mediation of any payment in money (TERRANOVA, 2003). For Terranova (2003), a part of free labor is also encouraging workers to get in touch with the changes occurring in the world with regard to knowledge and information, which activity is always exercised at the moment of non-work or leisure.

We are constantly being invited to contribute to something, which, according to Terranova (2003), means we are being blatantly exploited in our daily work routine and, above all, in our daily lives. If we return to the idea of co-creation according to Prahalad and Ramaswamy (2004a, 2004b), companies have always been concerned with their ability to access the specialist competences and skills of consumers. For Zwick, Bonsu and Darmody (2008), in addition to attracting and retaining consumers, companies are concerned with providing a creative environment with free communication, where consumers (also understood as workers) can apply and improve their knowledge so that "everybody" benefits. It is these characteristic spaces of the post-Fordist era that make it possible for human intelligence to renew its capacity to produce, in which, given the exploitation of the labor force (see LAZZARATO and NEGRI, 2001), the worker-consumer is the most pervasive and productive form of labor.

\section{FINAL CONSIDERATIONS}

While in López-Ruiz (2009) we see that executives seek to update their knowledge to continue being part of the organization, in this research we see young people making an effort to belong in a different way, not by updating their studies - since they are still undergraduate students - but by way of their relationship with the brand, which is expressed in their posts, retweets and comments on social networks, etc. Our study shows that the lifestyle of young people has been affecting their relationship with the employer brand, which wants to take control of young people's lifestyle with the intention of them increasingly becoming prosumers. People management policies as such, however, are not enough to keep these young people in organizations.

Apart from this, we can infer that career has been increasingly shown to be an undertaking that is associated with intermittent work, which makes working relationships increasingly vulnerable. From the studies that say that a career is "I corporation" or "the self-manager", now workers are being co-opted and seduced by the brand; even - it is important to point out - if only for a brief moment.

Employer brand companies, with their people management policies, cannot retain young people for long periods of time. Even if companies invest in the brand (by sharing corporate content on social networks, which characterizes work outside the contractual time), these young people do not want to remain in the company. Here we see the hedonism of youth, which is characterized by ephemeral relationships with either people or with organizations. Reputation and building a résumé are supported by these brand names. Young people incorporate the discourse of the employer brand, even if in order to do so they have to invest in voluntary work, which takes over the whole of their lives time-wise.

There is an affective dimension in the relationship between interns and employer brand companies, in the sense that the latter seek to put the affections of prosumer interns 'to work', a process that is largely mediated by new technologies (social networks, the Internet). That is why identification and the subsequent retention of the prosumer intern is so important, because the company will be able to take deliberate advantage of the affection that is created between it and the employee 
and that results in the company being publicly declared a good place to work, which is something that can strengthen its brand management.

Studies on the changing profile of professionals over time had already predicted that workers would need other competences, and forecast that today it would be almost impossible to remain for 10-20 years in the same company. It is believed that this change says as much about young people's desires, as it does about the instability that is found in Brazilian labor relations.

With regard to people management policies, young people refer to the seduction that is strategically exerted by such policies. We also notice that employer brand companies are obliged to be better when it comes to implementing their attraction and retention policies, because they are not just aiming at young students, but at prosumers, at co-creators who interact differently with them.

In concluding, we consider that the number of interviewees is a limitation of this study. Other than that, it has to be emphasized that this is a regional study that only considered one federal university, and specifically from one state in southern Brazil. We suggest that future studies should continue the dialogue between people management policies, new lifestyles and consumption. On the positive side, it should be noted again that we brought the prosumer closer to employer branding. We believe it is also worth researching to what extent the instability in these relationships is anchored in Brazilian labor relations. 


\section{REFERENCES}

ABÍLIO, L. C. O Make Up do Trabalho: uma empresa e um milhão de revendedoras de cosméticos. 2011. 307 p. Thesis (Doctor degree in Social Sciences) - Universidade Estadual de Campinas, Instituto de Filosofia e Ciências Humanas, Camopinas, 2011.

AGGERHOLM, H. K.; ANDERSEN, S. E.; THOMSEN, C. Conceptualizing employer branding in sustainable organizations. Corporate Communications: An International Journal, v. 16, n. 2, p. 105-123, 2011.

AIGRAIN, P.; AIGRAIN, S. Sharing: culture and the economy in the internet age. Amsterdam: Amsterdam University Press, 2012.

AMBLER, T.; BARROW, S. The employer brand. Journal of Brand Management, v. 4, n. 3, p. 185-206, 1996.

ANDREJEVIC, M. Estranged Free Labor. In: SCHOLZ, T. (Ed.). Digital Labor: the internet as playground and factory. New York: Routledge, 2013. p. 149-164.

APP, S.; MERK, J.; BUTTGEN, M. Employer Branding: Sustainable HRM as a Competitive Advantage in the Market for High - Quality Employees. Management Revue, v. 23, n. 3, p. 262-278, 2012.

ARVIDSSON, A. Brands: a critical perspective. Journal of Consumer Culture, v. 5 n. 2, p. 235-258, 2005.

ARVIDSSON, A. Brands: meaning and value in media culture. London: Routledge, 2006.

ARVIDSSON, A.; PEITERSEN, N. The Ethical Economy: Rebuilding Value after the Crisis. New York: Columbia University Press, 2013.

ARVIDSSON, A. The ethical economy of customer coproduction. Journal of Macromarketing, v. 28, n. 4, p. 326-338, 2008.

ARVIDSSON, A. The ethical economy: new forms of value in the information society. Organization. v.17, n. 5, p. 637-644, 2010.

BACKHAUS, K; TIKOO, S. Conceptualizing and researching employer branding. Carreer Development International, v. 9, n. 5, p. 501 517, 2004.

BARDIN, L. Análise de Conteúdo. São Paulo: Edições, 2016.

BAUDRILLARD, J. A Sociedade de Consumo. Lisboa: Edições 70, 2005.

BAUMAN, Z. Vida líquida. Rio de Janeiro: Jorge Zahar, 2007.

BAUMAN, Z. Medo líquido. Rio de Janeiro: Jorge Zahar, 2008.

BERTHON, P.; EWING, M.; HAH, L. L. Captivating company: dimensions of attractiveness in employer branding. International Journal of Advertising: The Review of Marketing Communications, v. 24, n. 2, p. 151-172, 2005.

BOTSMAN, R.; ROGERS, R. What's mine is yours: how collaborative consumption is changing the way we live. London: Collins, 2011.

CHERTKOVSKAYA, E. et al. Giving notice to employability. Ephemera: theory \& politics in organization, v. 13, n. 4, p. 701-716, 2013.

CHHABRA, N. L.; SHARMA, S. Employer branding: strategy for improving employer attractiveness. International Journal of Organizational Analysis, v. 22, n. 1, p. 4-60, 2014.

CHURCHILL, G. A; PETER, J. P. Marketing: criando valor para os clientes. São Paulo: Saraiva, 2003.
COMOR, E. Contextualizing and Critiquing the Fantastic Prosumer: Power, Alienation and Hegemony. Critical Sociology, v. 37, n. 3, p. 309-327, 2010a.

COMOR, E. Digital prosumption and alienation. Ephemera: theory \& politics in organization, v. 10, n. 3-4, p. 439-454, 2010b.

CÓRDOVA, R. G. Interfaces entre trabalho e consumo: uma proposta de discussão acerca das definições sobre o processo de cocriação. In: ENCONTRO NACIONAL DOS ESTUDOS DO CONSUMO (ENEC), 8., 2016, Niterói. Anais... Niterói: ENEC, 2016.

DALE, K. The employee as 'dish of the day': The ethics of the consuming/ consumed self in human resources management. Journal of Business Ethics, v. 111, n. 1, p. 13-24, 2012.

DELL, D. J.; AINSPAN, N. Engaging employees through your brand. In: THE CONFERENCE BOARD OF CANADA, 2001, Ottawa. Proceedings... New York: Conference Board, 2011.

FLICK, U. Uma introdução à pesquisa qualitativa. Porto Alegre: Bookman, 2004.

FONTENELLE, I. A. O Estatuto do Consumo na Compreensão da Logística e das Mutações do Capitalismo. Lua Nova: Revista de Cultura e Política, São Paulo, v. I, n. 92, p. 207-240, 2014.

FONTENELLE, I. A. Organizations as producers of consumers. Organization, London, v. 22, n. 5, p. 644-660, 2015 a.

FONTENELLE, I. A. Prosumption: As Novas Articulações entre Trabalho e Consumo na Reorganização do Capital. Revista Ciências Sociais Unisinos, v. 51, n. 1, p. 83-91, 2015b.

FONTENELLE, I. A. O Fetiche do Eu Autônomo: Consumo Responsável, Excesso e Redenção como Mercadoria. Psicologia \& Sociedade, v. 22, p. 215-224, 2010.

FONTENELLE, I. A. Global Responsibility through Consumption? Resistance and assimilation in the anti-brand movement. Critical perspectives on international Business, v. 6, p. 256-272, 2010.

GABRIEL, Y.; LANG, T. The Unmanageable Consumer: Contemporary Consumption and its fragmentations. London: Sage Publications, 2008.

GILL, R.; PRATT, A. Precarity and Cultural Work in the Social Factory? Immaterial Labour, Precariousness and Cultural Work. Theory, Culture \& Society, v. 25, n. 7-8, p. 1-30, 2008.

GORZ, A. Metamorfoses do trabalho: crítica da razão econômica. São Paulo: Annablume, 2003.

HESMONDHALGH, D. User-generated content, free labour and cultural industries. Ephemera: theory \& politics in organization, v. 10, n. 3-4, p. 267-284, 2010.

KEENOY, T. HRM as hologram: A polemic. Journal of Management Studies, v. 41, n. 3, p. 1-23, 1999.

LAND, C.; TAYLOR, S. Surf's Up: Work, balance and brand in a new age capitalist organization. Sociology (British Sociological Association), v. 44, n. 3, p. 395-413, 2010.

LAZZARATO, M.; NEGRI, A. Trabalho Imaterial: formas de vida e produção de subjetividade. Rio de Janeiro: DP\&A, 2001. 
LEGGE, K. Human Resource Management: Rhetorics and Realities (Anniversary ed.). Basingstoke: Palgrave MacMillan, 2005.

LIPOVETSKY, G. O império do efêmero: a moda e seu destino nas sociedades modernas. São Paulo: Companhia das Letras, 1989.

LÓPEZ-RUIZ, O. Os executivos das transnacionais e o espírito do capitalismo: Capital humano e empreendedorismo como valores sociais. São Paulo: Azougue Editorial, 2007.

LOURO, M. J. S. Modelos de Avaliação de Marca. Revista de Administração de Empresas, v. 40, n. 2, p. 26-37, 2000.

MINAYO, M. C. S. (Org.). Pesquisa social: teoria, método e criatividade. Petrópolis: Vozes, 2001.

MORAES, R. Análise textual discursiva. Porto Alegre: Unijuí, 2007.

OLIVEIRA, F. O ornitorrinco. São Paulo: Boitempo, 2003.

OLIVEIRA, L, B.; HONÓRIO, S. R. F. S. Atração e desligamento voluntário de jovens empregados: um estudo de caso no setor jornalístico. Revista de Administração - RAUSP, v. 49, n. 4, p. 714-730, 2014.

OLTRAMARI, A.; GRISCI, C. L. Carreira e família na sociedade líquidomoderna. Revista de Administração Mackenzie, v. 15, n. 1, p. 15-48, 2014.

OLTRAMARI, A.; TONELLI, M. J.; COSTA, A. C. Employer Branding: Análise Das Estratégias Narrativas de Marcas Empregadoras para Atração e Retenção de Trabalhadores. In: ENCONTRO DE GESTÃO DE PESSOAS E RELAÇÕES DE TRABALHO, 5., 2015, Salvador. Anais... Salvador: EnGPR, 2015.

OLTRAMARI, A. Transição na carreira e quantofrenia: um estudo de caso com coordenadores de mestrado e doutorado de uma IES privada. Revista de Carreira e Pessoas, v. 5, n. 2, p. 200-210, 2015.

PEARCE, J. L. Volunteers: The organizational behavior of unpaid workers. London: Routledge, 1993.

PRAHALAD, C. K.; RAMASWAMY, V. Co-creation experiences: the next practice in value creation. Journal of Interactive Marketing, v. 18, n. 3 , p. $5-14,2004 a$.

PRAHALAD, C. K.; RAMASWAMY, V. The future of competition: co-creating unique value with customers. Boston: Harvard University Press, 2004b.
REIS, G. G.; BRAGA, B. M. Employer attractiveness from a generational perspective: Implications for employer branding. Revista de Administração, v. 51, n. 1, p. 103-116, 2016.

RITZER, G.; DEAN, P.; JURGENSON, N. The Coming of Age of the Prosumer. American Behavioral Scientist, v. 56, n. 4, p. 379-398, 2012.

RITZER, G.; GOODMAN, D.; WIEDENHOFT, W. Theories of consumption. In: RITZER, G.; SMART, B. (Eds.). Handbook of Social Theory. London: Sage, 2001. p. 410-427.

RITZER, G. Prosumption, evolution, revolution, or eternal return of the same? Journal of Consumer Culture, v. 14, n. 1, p. 3-24, 2014.

ROCHA-DE-OLIVEIRA, S. R.; PICCININI, V. C.; BITENCOURT, B. M. Juventudes, gerações e trabalho: é possível falar em geração Y no Brasil? Organizações \& Sociedade, v. 19, n. 62, p. 551-558, 2012.

SIVERTZEN, A.; NILSEN, R.; OLAFSEN, A. H. Employer branding: employer attractiveness and the use of social media. Journal of Product \& Brand Management, v. 22, n. 7, p. 473-483, 2013.

SYMON, G.; CASSEL, C. Qualitative organizational research: core methods and current challenges. London: Sage, 2012.

TASPCOTT, D.; WILLIAMS, A. D. Wikinomics: how mass collaboration changes everything. New York: Portfolio, 2010.

TERRANOVA, T. Free Labor: producing culture for the digital economy. 2003. Available at: <http://www.electronicbookreview.com/thread/ technocapitalism/voluntary>. Accessed on: Dec. 12, 2016.

TOFFLER, A. A terceira onda. Rio de Janeiro: Record, 1980.

TOWNLEY, B. Managing with modernity. Organization, v. 9, n. 4, p. $549-573,2002$.

TRIVIÑOS, A. N. B. Introdução à pesquisa em ciências sociais: A pesquisa qualitativa em educação. São Paulo: Atlas, 1987.

WILDEN, R.; GUDERGAN, S.; LINGS, I. Employer branding: strategic implications for staff recruitment. Journal of Marketing Management, v. 26, n. 1-2, p. 56-73, 2010.

ZWICK, D.; BONSU, S. K.; DARMODY, A. Putting consumers to work: Co-creation and new marketing govern-mentality. Journal of Consumer Culture, v. 8, n. 2, p. 163-196, 2008. 
Andrea Poleto Oltramari

ORCID: https://orcid.org/0000-0002-5897-2772

Doctor of Business Administration at Federal University of Rio Grande do Sul (PPGA/UFRGS); Assistant Professor at Federal University of Rio Grande do Sul (UFRGS), Porto Alegre - RS, Brazil. E-mail: andrea.oltramari@ufrgs.br

Rosana Córdova

ORCID: https://orcid.org/0000-0002-5120-1385

Doctor of Business Administration at Fundação Getulio Vargas (FGV EAESP); Assistant Professor at Federal University of Rio Grande do Sul (UFRGS), Porto Alegre - RS, Brazil. E-mail: rosana.cordova@ufrgs.br

Maria José Tonelli

ORCID: https://orcid.org/0000-0002-6585-1493

Professor of the General Administration and Human Resources Department at Fundação Getulio Vargas (FGV EAESP), São Paulo - SP, Brazil. E-mail: maria.jose.tonelli@fgv.br 